UDC 550.47

DOI: $10.21668 /$ health.risk/2018.3.15.eng

\title{
PROPORTIONS OF ARSENIC AND ANTIMONY IN BIOGEOCHEMICAL PROVINCES AS HEALTH RISK FACTORS
}

\author{
V.V. Turbinsky ${ }^{1}$, S.B. Bortnikova ${ }^{2}$ \\ ${ }^{1}$ Novosibirsk State Medical University, 52 Krasny Prospect, Novosibirsk, 630091, Russian Federation \\ ${ }^{2}$ Trofimuk Institute ofPetroleum Geologyand Geophysics of Siberian Branch of Russian Academy of Sciences, 3 \\ Koptugavenue, Novosibirsk, 630090, Russian Federation
}

To perform efficient activities aimed at managing population health risks, it is necessary to examine regularities related to distribution of chemical elements in the biosphere; especially in so called biogeochemical provinces of natural or technogenic origin. We used semimetals of arsenic and antimony as an example to show that similarity of their physical and chemical properties is accompanied with similar effects they produce on living organisms. However, amphoteric character of arsenic and antimony determines wide range of possible interactions between these elements and biological molecules in a body. As a result, combined influence exerted by these substances on living organisms leads to both antagonistic relations and competition between them and to synergy as well. Basing on reviewed literature data, we showed that animals selectively limited accumulation of arsenic in their bodies and consumed less toxic antimony in greater quantities in case of biochemical anomalies while plants were much less selective and accumulated toxic arsenic easily. Accordingly, any activities aimed at population health risk reduction that are to be performed on territories of biogeochemical provinces should take into account peculiarities related to accumulation of these elements in bodies of warm-blooded animals and people. These peculiarities should also be taken into account when hygienic research programs and hygienic inspections are drawn up. When such research is performed experts should do the following: to analyze ways and chemical forms of elements migration in the environment; to determine molecular mechanisms of elements penetration into a cell and conditions of various scenarios of their metabolism and biological efficiency.

Key words: arsenic and antimony compounds, biogeochemical provinces, biogeocenosis, population health, medical and prevention activities.

Live organisms existing within a specific biogeochemical province have to rearrange their life processes. It leads to a specific elements imbalance in a body that is to be eliminated with special medical and preventive technologies [1-4].

Absorption of chemical elements from the environment by warm-blooded organisms depends on chemical properties and aggregate state of an element, its quantity, accompanying elements, and properties of body tissues that contact it as well [5]. The conditions are multiple and it makes absorption of chemical elements by a body a truly situational process. Therefore, given specific con- ditions existing in this or that biogeochemical province, it is necessary to determine regularities of introduction, accumulation, and excretion out of a body for elements that are specific for it. Given this multiple dependency of toxic effects produced by chemicals, I.M. Trakhtenberg noted [6] that it was necessary to perform an obligatory examination of overall quantitative contamination of the environment in biogeochemical provinces in order to work out efficient preventive measures.

Biogeochemical anomalies, both natural and technogenic ones, have been studied for more than 50 years and it allowed to determine what

(C) Turbinsky V.V., Bortnikova S.B., 2018

Viktor V. Turbinsky - Doctor of Medical Sciences, Associate Professor, Professor at Hygiene and Ecology Department (e-mail:vvturbinski@ mail.ru; tel.: +7 (913) 776-37-58).

Svetlana B. Bortnikova - Doctor of Geological and Mineralogical Sciences, Professorp, Head of Geoelectrochemistry Laboratory (e-mail: BortnikovaSB @ipgg.sbras.ru; tel.: +7 (383) 363-91-95). 
substances occurred in them, as well as reasons and conditions for formation of biogeochemical provinces; to understand and formulate regularities related to their formation; to work out strategy and tactics of activities aimed at providing prevention of population health disorders [7]. Growth in industrial outputs requires new resource provision based on new technological solutions both in production and in exploration of new mineral deposits and in recultivation of previously used ones [8].

Arsenic is a widely spread element which is contained in a lot of minerals, especially metalscontaining ones. Arsenic is a metalloid, that is, it is a substance that is between metals and non-metals; so, if we want to get a better insight into regularities of its dispersion, it is interesting to analyze biogeochemical properties of other metalloids. We can take antimony as an example as it is another element that has been used by people from the earliest times and, what is also important, also accompanies a lot of other metals [9]. Antimony ( $\mathrm{Sb}$ ) and its compounds were enlisted among toxic or hazardous substances that require immediate attention on the 43th session of the World Health Assembly held in Geneva in $1990[10,11]$.

Metals and metalloids have a common capability to interact with sulfhydryl groups of biological molecules that participate in nervous impulses conduction, tissue respiration, muscle contraction, cellular membranes penetrability etc. A reaction between ions of metals and metalloids with $\mathrm{SH}$-groups results in occurrence of insoluble compounds, so called mercaptides, that leads to disorders in certain biochemical processes underlying development of intoxication [12].

Our research goal was to perform a comparative analysis of toxicometry and toxicokinetics parameters of arsenic and antimony under conditions of their biogeochemical anomaly.

Arsenic is unique due to its occurrence everywhere, in minerals, rocks, soils, and water, in plants and animals. Average arsenic concentration in rivers is equal to $3 \mu \mathrm{g} / \mathrm{l}$; in surface waters, about
$10 \mu \mathrm{g} / \mathrm{l}$; in seas and oceans, just about $1 \mu \mathrm{g} / \mathrm{l}^{1}$. Arsenic concentration in soils usually varies from 0.1 to $40 \mathrm{mg} / \mathrm{kg}$. Much greater quantities of arsenic, up to 8 $\mathrm{g} / \mathrm{kg}$, can be found in areas where arsenic ores occur, as well as in volcanic regions [13].

Increased arsenic concentrations in soils can exert negative influence on agricultural crops due to arsenic becoming a food chain component [14]. Geochemical background of arsenic (As) which is detected in landscape components around tailings dams of mining enterprises is characterized with high arsenic pollution, namely $57-300 \mathrm{mg} / \mathrm{kg}$ [15]. Arsenic concentration in plants that grow on a territory of natural-technogenic landscapes varies considerably, from such low values as 0.001 to $847.29 \mathrm{mg} / \mathrm{kg}$. Average arsenic contents in plants growing in this landscape are 2.7 times higher than in plants growing in quarry-dump landscapes and almost 28 times higher than in plants growing in natural landscapes [15]. Arsenic also migrates in the environment in a form of volatile arsenicorganic compounds [13].

Arsenic concentration in a living organism usually amounts to about $6 \mu \mathrm{g} / \mathrm{kg}$. Daily introduction of arsenic into a human body is insignificant and varies from 50 to $100 \mu \mathrm{g}$, and its semiexcretion period amounts to $30-60$ hours $^{2}$. When arsenic enters a body, it then concentrates in the thyroid gland, liver, kidneys, spleen, lungs, bones, hair, brain tissues, and the muscles. There are some data on arsenic accumulation in the thyroid gland making for endemic goiter development [16].

Chronic negative effects produced by arsenic are damage to skin, neurotoxicity, cardiovascular diseases, diabetes, and cancer. The International Agency for Research on Cancer (IARC) rank arsenic and its non-organic compounds as "Carcinogenic to Humans" (group I) (IARC, 1980[17]). EFSA Food Contamination Panel detected that provisional tolerable weekly intake of arsenic shouldn't exceed $15 \mu \mathrm{g} / \mathrm{kg}$ *day (EFSA contam PANEL, 2009) $)^{3}$ [18].

Geometric average arsenic concentrations in

${ }^{1}$ Turbinskiy V.V. Hygienic grounds for sanitary protection of cross-border and border sources of drinking water supply for the RF population: dissertation ...for Doctor Of Medical Sciences. Novosibirsk, 2012. 376 p. Available at: http://www.dissercat.com/content/gigienicheskie-osnovy-sanitarnoi-okhrany-transgranichnykh-ipogranichnykh-istochnikov-pitevo (date of visit February 13, 2018).

${ }^{2}$ Chemical structure of Russian food products: reference book. In: I.M. Skurikhin ed. Moscow, Deli print Publ., 2002, 236 p.

${ }^{3} \mathrm{P}$ 2.1.10.1920-04. Guidelines on assessment of population health risk under exposure to chemicals that pollute environment. Moscow, Federal center for Sanitary and Epidemiologic Surveillance of The RF Public healthcare Ministry Publ., 2004,143 p. 
umbilical blood of parturient women are equal to $0.92 \pm 1.01 \mathrm{ng} / \mathrm{ml}$, at $0.43 \pm 0.88 \mathrm{ng} / \mathrm{ml}(\mathrm{n}=296)$ in healthy newborns [19]. An inhibition of arsenic elimination out of a body was detected under single oral exposure to arsenous anhydride in a dose equal to $30 \mathrm{mg} / \mathrm{kg}$ which coincided with a threshold of acute action produced by arsenous anhydride on changes in SH-group contents in blood ${ }^{4}$.

Arsenic concentration in chicken that consumed it with forage in a dose equal to 0.5-5.0 $\mathrm{mg} / \mathrm{kg}$ amounted to $0.11-0.2 \mathrm{mg} / \mathrm{kg}$ in muscle tissues; $0.09-0.12 \mathrm{mg} / \mathrm{kg}$ in liver; $0.09-0.34 \mathrm{mg} / \mathrm{kg}$ in kidneys; and $0.12-0.21 \mathrm{mg} / \mathrm{kg}$ in eggs ${ }^{5}$.

Oral introduction of arsenic oxide $\left(\mathrm{As}_{2} \mathrm{O}_{3}\right)$ into sheep bodies in a dose equal to $0.5 \mathrm{mg} / \mathrm{kg}$ of an animal body weight didn't cause any clinical intoxication symptoms during 3 months after exposure. But arsenic accumulated in a dose equal to 0.2-0.3 mg-kg in the kidneys, skin, liver, and spleen; about $0.12 \mathrm{mg} / \mathrm{kg}$, in muscle tissues and lungs; about $0.25-0.3 \mathrm{mg} / \mathrm{kg}$, in the abomasum, duodenum, jejunum, and ileum [20].

High arsenic concentrations in drinking water, $200-500 \mu \mathrm{g} / \mathrm{l}$, are toxic for the human endocrine system [21]. Cumulative exposures to arsenic with food and drinking water are higher in people suffering from the II type diabetes than in healthy people $[22,23]$ and it proves it is necessary to conduct further research on a role played by moderate and low arsenic concentrations (500-200 $\mu \mathrm{g} / \mathrm{l})$ in water [24].

Experts used models of animal cells cultures to show that arsenic acted as endocrine destroyer. They detected disorders in gene expression of steroid receptor (SR) in cells exposed to nonorganic arsenic (arsenite, iAs $(+3)$ ). Low iAs $(+3)$ concentrations $(0.1-0.7 \mu \mathrm{M})$ stimulate hormoneinduced transcription, but higher non-cytotoxic arsenic concentrations (1-3 $\mu \mathrm{M})$ inhibit transcription [25].

Antimony is a considerably rare element in the earth's crust, $4^{*} 10^{-5} \%$, although it, like arsenic, can occur in high concentrations in some regions [26]. In nature antimony usually has valence +3 , more rarely +5 [27]. Compounds of tervalent posi- tive antimony (sulfides, thiosalts, antimonites, trioxide) are most widely spread; the next place belongs to compounds of tervalent negative antimony (antimonides). Compounds of pentavalent antimony are rarely met in nature. Antimonial glitter $\mathrm{Sb}_{2} \mathrm{~S}_{3}$ (stibuite, antimonite) is the most widely spread antimony-containing mineral; it occurs in hydrothermal deposits as antimonial ores seams and tabular deposits [28].

Background antimony concentrations in upper soils layers amount to $0.76 \mathrm{mg} / \mathrm{kg}$ in sod-podzol soils; $0.99 \mathrm{mg} / \mathrm{kg}$, in black earth; $0.28 \mathrm{mg} / \mathrm{kg}$, in peaty soils. Antimony concentrations in Siberian rivers (Irtysh, Ob', Tom' and Amur) amounts to $0.0007-0.002 \mathrm{mg} / \mathrm{dm}^{35}$.

Antimony concentrations in tissues of trees and bushes that grow in areas with ores mineralization reach $7-50 \mathrm{mg} / \mathrm{kg}$ of dry solid matter; its average concentrations in plants parts above ground level amounts to $0.06 \mathrm{mg} / \mathrm{kg}$ of dry solid matter. Antimony concentrations in edible plants vary within $0.02-4.3 \mu \mathrm{g} / \mathrm{kg}$ of raw matter. Antimony concentration in corn grains and potato tubers doesn't exceed $2 \mu \mathrm{g} / \mathrm{kg}$ of dry solid matter; it reaches $29 \mu \mathrm{g} / \mathrm{kg}$ in grass. Antimony concentration in barley and flax rootage amounts to 122 and 167 $\mu \mathrm{g} / \mathrm{kg}$ of solid dry matter respectively, and it is considerably higher than in leaves where it amounts to 10 and $27 \mu \mathrm{g} / \mathrm{kg}$ of solid dry matter [28]. As concentrations of heavy metals in soils become very high, their concentrations in various parts of plants also increase. But a ratio between heavy metals concentrations in rots, culms, leaves, and reproductive organs is preserved.

Complex research performed on Dyukov Log waste storage where sulfide-containing wastes from Salairskiy ore mining and processing enterprise were kept helped to outline migration routes for drainage flows that contained increased antimony concentrations (96 MPC) and arsenic concentrations (6 MPC). It was detected that polluted drainage water penetrated water-bearing horizons that, among other things, were used as water supply sources for communal needs and drinking [29]. Plants growing on pasture lands and land-

\footnotetext{
${ }^{4}$ Zhuruli M.O. Studies on toxicokinetics of arsenous anhydride under various exposure in order to fix hygienic standards: dissertation....Candidate of Medical Sciences. Moscow, 1984, 179 p. Available at: http://www.dissercat.com/content/izuchenie-toksikokinetiki-myshyakovistogo-angidrida-pri-razlichnykhrezhimakh-ego-vozdeistvi\#ixzz5CNZZqPjy (date of visit January 19, 2018).

${ }^{5}$ Chupakhina O.K. Toxicity of arsenic for chicken and its distribution in poultry organs and tissues: thesis of dissertation...Candidate of Veterinary Sciences. Moscow, 1983, 21 p.
} 
scape plants in Kadamjaiskaya biogeochemical antimony province accumulate substantial antimony concentrations, $1.2-16$ MPC.

As per data obtained in some research, antimony can be found in a human body: in blood, $0.0033 \mathrm{mg} / \mathrm{l}$; bone tissue, $(0.01-0.6) * 10-4 \%$; muscle tissues, $(0.42-19.1) * 10-6 \%$; a toxic dose amounts to $100 \mathrm{mg}$. Average daily introduction of antimony into a human body with food and water amounts to approximately $50 \mu \mathrm{m}$. Antimony is rather slowly excreted from a body [30, 31].

Antimony in concentrations equal to 0.41 $0.55 \mathrm{mg} / \mathrm{kg}$ and arsenic in concentrations equal to $0.79-0.82 \mathrm{mg} / \mathrm{kg}$ were detected in bone fragments belonging to a gray rat Rattus Norvegicus found in pellets of a long-eared owl that usually spends a winter in Tashkent and adjacent territories [32].

Elimination of antimony is equally related to its valence in a specific compound. Thus, when antimony trioxide was added to rats forage, 80-100 $\mu \mathrm{m}$ of this metal were daily excreted with urine, and up to $100 \mathrm{mg}$, with stool. Pentavalent antimony is primarily excreted with urine even when it is introduced intragastrically [33].

Antimony $(\mathrm{Sb})$ is similar to arsenic as per its properties; it was detected that antimony exerted inhibiting influence on enzymes that participate in carbohydrates, fats, and lipids metabolism. Just as arsenic, antimony reacts with sulfhydryl groups, has toxic properties, can probably cause immune deficiency [34], and causes functional disorders in various organs (heart, kidneys, CNS, liver, lungs, intestines, lymphatic system and others) [35, 36].

Inhalation exposure to antimony aerosols that occur in working area air causes its higher concentrations in workers' bodies; they increase from $0.5 \mathrm{mg} \%$ to $2.1 \mathrm{mg} \%$ in blood; from 0.86 $\mathrm{mg} \%$ to $1.86 \mathrm{mg} \%$ in urine; from $1.6 \mathrm{mg} \%$ to 7,8 $\mathrm{mg} \%$ in hair [37].

Fivefold intraperitoneal introduction of metal antimony suspension in peach oil into white rats in a dose equal to $50 \mathrm{mg} / \mathrm{kg}$ of a body weight caused increased antimony concentrations in blood $(10.46+1.22 ; 6.58+0.74 \mathrm{mg} \%)$. Antimony accumulated in internal organs in the following concentrations: muscles, $1.49 \pm 0.35 \mathrm{mg} \%$; lungs, $1.38+$ $\pm 0.2 \mathrm{mg} \%$; skin, $1.14+0.3 \mathrm{mg} \%$ [38].

Antimony concentrations in sheep bodies on a territory of antimony biogeochemical province amount to $3.66-12.7 \mathrm{mg} / \mathrm{kg}$ in the heart; 4.00 $12.16 \mathrm{mg} / \mathrm{kg}$, lungs; $2.6-10.2 \mathrm{mg} / \mathrm{kg}$, kidneys; 3.6 $10.0 \mathrm{mg} / \mathrm{kg}$, muscles; concentration gradient is $2-$ 2.4 [39]. Daily antimony introduction into a human body detected in Kadamdjayskaya antimony province, Republic of Kirgizstan, amounts to $8.54 \mathrm{mg}$ while it is equal to only $1.22 \mathrm{mg}$ per day on a reference territory [40], and a reference dose of antimony for chronic oral introduction into a body amounts to $0.0004 \mathrm{mg} / \mathrm{kg}$. This increased antimony introduction exerts its negative influence primarily on dextrose and cholesterol contents in blood ${ }^{3}$.

Table

Arsenic/antimony ratio in geological and biological environment in biogeochemical provinces

\begin{tabular}{|l|c|c|c|}
\hline Environmental object & $\begin{array}{c}\text { Arsenic, } \mathrm{mg} / \mathrm{kg} \\
\text { min-max } \\
\text { average }\end{array}$ & $\begin{array}{c}\text { Antimony, } \mathrm{mg} / \mathrm{kg} \\
\text { min-max } \\
\text { average }\end{array}$ & Average As/Sb ratio \\
\hline Soil & $0,1-40,0$ & $0,28-0,99$ & 0,76 \\
\hline Water & 10,0 & $0,00005-0,0007$ & 13,1 \\
\hline Plants (antimony and arsenic biogeo- & $0,0007-0,005$ & 0,00037 & 7,8 \\
chemical province) & 0,0029 & $7-50$ & 5,0 \\
Background (reference territory) & 100 & 20 & 2,0 \\
\hline Animals: & $0-6,01$ & $0,02-4,3$ & - \\
- wild rats (bones) & 1,4 & $0,71-0,55$ & 0,14 \\
\hline - sheep (lungs, kidneys, muscles) & $0,79-0,82$ & 0,47 & 0,21 \\
\hline - people (blood) & 0,80 & $6,41-8,08$ & 0,2 \\
\hline Threshold toxic does, mg/day & $0,41-1,54$ & 7,25 & 0,24 \\
\hline Lethal dose for a man, mg & $0,43-0,92$ & 3,3 & 3,3 \\
\hline
\end{tabular}


Research conducted in antimony biogeochemical provinces located in Fergana Valley revealed that adult population living there daily consumed approximately $0.1-0.15 \mathrm{mg}$ of antimony with food and water and it was 10-15 times higher than a usual introduction on a reference territory [41].

Each pathology has its specific element structure and concentrations, including maximum ones, as well as changes in an aggregate parameter of their accumulation [42-44]. Antimony and arsenic are endocrine destroyers [45].

$\mathrm{As} / \mathrm{Sb}$ ratios are obtained on the basis of collected data on arsenic and antimony concentrations in geological and biological objects. The results are shown in the Table.

The obtained ratios show that arsenic concentrations are 2-13 times higher than antimony ones in geological environmental objects, and, on the contrary, antimony concentrations are 5-20 times higher in biological media of living organisms. Arsenic contents in bones is 1.7 times higher than antimony contents, just like in geological objects.

Higher antimony concentrations than arsenic ones in a body are determined by antimony being less toxic than arsenic.
Therefore, plants are less selective and tend to accumulate toxic arsenic easily when growing in biogeochemical anomalies while animals selectively limit its introduction into their bodies and try to consume less toxic antimony instead. Accordingly, all medical and prevention activities performed in biogeochemical provinces with increased arsenic and antimony occurrence are to take into account peculiarities of these elements accumulation in bodies of warm-blooded animals and people. Programs for in-depth research within hygienic examinations, inspections, or investigations should also take these peculiarities into account. Research should include analysis of directions and chemical forms in which elements migrate in the environment, establishment of molecular mechanisms with which elements penetrate into a cell, and conditions for various scenarios of their metabolism and biological activity.

Funding.This work was supported by the Russian Foundation for Basic Research (Grant No. 17-05-00056).

Conflict of interest. The authors state there is no conflict of interest.

\section{References}

1. Efimova N.V., Myl'nikova I.V., Katul'skaya O.Yu., D'yakovich M.P. Problemyadaptatsiidetei i podrostkov v usloviyakh Vostochnoi Sibiri: monografiya [Issues related to adaptation of children and teenagers in eastern Siberia: Monograph]. Irkutsk, RIO GBOU DPO IGMAPO Publ., 2012, 140 p. (in Russian).

2. D'yakovich M.P., Rukavishnikov V.S., Kazakova P.V., Finogenko I.A., Bokmel'der E.P., Solov'eva I.Yu. Kachestvozhizni, svyazannoesozdorov'em: otsenka i upravlenie [Health-related life quality: assessment and management]. In: V.S. Rukavishnikoved. Irkutsk, NTsRVKh SO RAMN Publ., 2012, 168 p. (in Russian).

3. Gurvich V.B., Plotko E.G., Kuzmin S.V., Selyankina K.P., Ryzhov V.V., Makarenko N.P., Nadeenko V.G. Aktual'nyeproblemyprofilakticheskoimeditsiny v Ural'skomregione [Vital issues of preventive medicine in the Urals]. Sbornik nauchnykh trudov i nauchno-prakticheskikh rabot, posvyashchennyi 80-letiyu gossanepidsluzhby Rossii. Ekaterinburg, 2002, p. 76-81 (in Russian).

4. Kovalevskii A.L. Biogeokhimicheskiepoiskirudnykhmestorozhdenii [Biogeochemical searching for ore deposits]. The2rded. Moscow, Nedra Publ., 1984, 172 p. (in Russian).

5. AvtsynA.P. Mikroelementozycheloveka: etiologiya, klassifikatsiya, organopatologiya [Human microelementosis: etiology, classification, and organopathology]. Moscow, Meditsina Publ., 1991, 496 p. (inRussian).

6. Trakhtenberg I.M. Narusheniekhimicheskogoravnovesiyakakprichinaboleznei [Chemical balance disorder as a cause of diseases]. Zdorov'yaUkraini: meditsinskii portal. Availableat: http:Iwww.healthua.com (04.02.2018) (inRussian).

7. Osipov V.I., Aksyutin O.E., Ishkov A.G., Grachev V.A. Vzaimodeistvie cheloveka s prirodnoi sredoi - vazhneishii factor sushchestvovaniya tsivilizatsii itogam goda ekologii v rossiiposvyashchaetsya [Interaction between a man and the environment as a vital factor of civilization existence: dedication to 
the results of the Environmental Year in Russia]. Vestnik Rossiiskoi akademii nauk, 2018, vol. 88, no. 2, pp. 99-106. DOI: 10.7868/S0869587318020019 (in Russian).

8. Ivanter V.V. Perspektivy vosstanovleniya ekonomicheskogo rosta v Rossii [Prospects for recovery of economic growth in Russia]. Vestnik Rossiiskoi akademii nauk, 2017, vol. 87, no. 1, pp. 15-28 (in Russian).

9. Mel'nikov S.M., Rozlovskii A.A., Shuklin A.M. [et al.]. Sur'ma [Antimony].In: S.M. Mel'nikov ed. Moscow, Metallurgiya Puibl., 1977, 535 p. (in Russian).

10. Solodukhina M.A., Yurgenson G.A. Sur'ma v stepnykhpochvakh, tekhnozemakhiartemisiagmelinii weber ex stechmsherlovogorskogo rudnogo raiona (vostochnoe zabaikal'e) [Antimony in the steppe soils, technoself and artemisiagmelinii weber ex stechmsherlovogorskoe ore district (eastern Transbaikalia)]. Uspekhi sovremennogo estestvoznaniya, 2017, no. 4, pp. 114-119 (in Russian).

11. Hoet P., Lauwerys R. Metally I metalloorganicheskie soedineniya [Metals and metal-organic compounds]. Available

http://base.safework.ru/iloenc?navigator\&spack=110LogLength\%3D0\%26LogNumDoc\%3D8574000 33\%26listid\%3D0

10000000100\%26listpos\%3D2\%261sz\%3D6\%26nd\%3D857400033\%26nh\%3D1\%26 (29.01.2018) (in Russian).

12. Tiolovyeyady, mekhanizmdeistviya [Thiol poisons, action mechanisms]. Available at: https://studopedia.org/5-77519.html (11.02.2018) (in Russian).

13. Mysh'yak v prirode [Arsenic in nature]. Vuzlit.ru. Available at: https://vuzlit.ru/740028/myshyak_prirode (18.02.2018) (in Russian).

14. Schwarzkopfova K., Farago T., Jurkovič L. Mobilization of arsenic from technosols in a shortterm dynamic column experiment. Toxicological \& Environmental Chemistry. Available at: https://doi.org/10.1080/02772248.2018.1443339 (22.03.2018).

15. Mikhailova L.A., Solodukhina M.A. Prirodnye i antropogennye geokhimicheskie anomalii Zabaikal'skogo kraya [Geochemical environment and public health in the Zabaykalye region]. Sovremennye problemy nauki i obrazovaniya, 2016, no. 5, p. 310 (in Russian).

16. Toksikologo-gigienicheskaya kharakteristika mysh'yaka [Toxicological and hygienic characteristics of arsenic]. Maga Lektsii. Available at: https://megalektsii.ru/s43057t1.html (21.03.2018) (in Russian).

17. IARC on the evaluation of the carcinogenic risk of chemicals to humans: Sorne Antineoplastic and Irnmunosuppressive Agent. World Health Organization; International Agency for Research on Cance. Lyon, 1981, vol. 26, 396 p.

18. Scientific Opinion on Arsenic in Food. EFSA Journal, 2009, vol. 7, no. 10, pp.1351. DOI: 10.2903/j.efsa.2009.1351

19. Lin Z., Chen X., Xi Z., Lin S., Sun X., Jiang X., Tian H. Individual heavy metal exposure and birth outcomes in Shenqiu county along the Huai River Basin in China. Toxicology Research, 2018, no. 3. Available at: http://pubs.rsc.org/en/Content/ArticleLanding/2018/TX/C8TX00009C\#!divAbstract (21.04.2018).

20. Zhulenko V.N., Golubitskaya A.V. Ekspress-metody opredeleniya metallosoderzhashchikh soedineniii mysh'yaka v biomateriale, kormakh [Express-tests for determining metal-containing compounds and arsenic in biological materials and feedstuffs]. Obninsk, 1992, 15 p. (in Russian).

21. Del Razo L.M., Garcia-Vargas G.G., Valenzuela O.L., Castellanos E.H., Sánchez-Peña L.C., Currier J.M., Drobná Z., Loomis D., Stýblo M.Exposuretoarsenic in drinking water is associated with increased prevalence of diabetes: a cross-sectional study in the Zimapán and Lagunera regions in Mexico. Environmental Health, 2011, no. 10, pp. 73-80. DOI: 10.1186/1476-069X-10-73

22. Makris K.C., Christophi C.A., Paisi M., Ettinger A.S. Apreliminaryassessmen to flow levelarsenicexposureanddiabetesmellitus in Cyprus. BMC Public Health, 2012, no. 12, pp. 334.

23. Steinmaus C., Yuan Y., Liaw J., Smith A.H. Low-level population exposure to inorganic arsenic in the United States and diabetes mellitus: a reanalysis. Epidemiology, 2009, vol. 20, no. 6, pp. 807-815.

24. Gosse J.A., Taylor V.F., Jackson B.P., Hamilton J.W., Bodwell J.E. Monomethylated trivalent arsenic species disrupt steroid receptor interactions with their DNA response elements at non-cytotoxic cellular concentrations. J. Appl Toxicol., 2014, vol. 34, no. 5, pp. 498-505. DOI: 10.1002/jat.2898

25. O vliyanie sur'my na organizm cheloveka (kratkii obzor literatury) [On influence exerted by antimony on a human body (short literature review)]. DocPlayer.ru. Available at: 
https://docplayer.ru/82958586-O-vliyanie-surmy-na-organizm-cheloveka-kratkiy-obzor-literatury.html (15.02.2018) (in Russian).

26. Raspredeleniesur'my v sistemepochva-rastenie [Distribution of antimony in plant-soil system]. Geolike.ru. Available at: http://geolike.ru/page/gl 1357.htm (22.01.2018) (in Russian).

27. Biokhimiya I toksikologiya soedinenii mysh'yaka, sur'myivismuta - [Biochemistry and toxicology of arsenic, antimony and bismuth compounds]. AllBest. Available at: https://otherreferats.allbest.ru/chemistry/00131620_0.html (22.04.2018) (in Russian).

28. Kubatbekov T.S., Aitmatov M.B., Ibraimakunov M. Sur'ma v prirodno-tekhnogennykh usloviyakh biosfery: voda, pochva, rasteniya [Antimony in natural-technogenic conditions of the biosphere: water, soil, plants].Vestnik Rossiiskogo universiteta druzhby narodov. Seriya: Agronomiya i zhivotnovodstvo, 2012, no. 4, pp. 56-60 (in Russian).

29. Epov M.I., Yurkevich N.V., Bortnikova S.B., Karin Yu.G., Saeva O.A. Opredelenie sostava gorno-rudnykh otkhodov geokhimicheskimi I geofizicheskimi metodami (na primere khvostokhranilishcha Salairskogo gorno-obogatitel'nogo kombinata) [Analysis of mine waste by geochemical and geophysical methods (a case study of the mine tailing dump of the Salair ore-processing plant)]. Geologiya i geofizika, 2017, no. 12, pp. 1944-1954 (in Russian).

30. Ershov Yu.A., Pleteneva T.V. Mekhanizm y toksicheskogo deistviya neorganicheskikh soedinenii [Toxic action mechanisms of non-organic compounds]. Mocow, Meditsina Publ., 1989, 271 p. (in Russian).

31. Gashev S.N., Bykova E.A. Osobennosti nakopleniya mikroelementov v organizme melkikh mlekopitayushchikh v usloviyakh urbanizatsii [Peculiarities of microelements accumulation in the organism of small mammals in the urbanization conditions]. Izvestiya Samarskogo nauchnogo tsentra Rossiiskoi akademii nauk, 2014, vol. 16, no. 1-4, pp. 1144-1148 (in Russian).

32. Levin E.N. Obshchaya toksikologiya metallov [Common toxicology of metals]. Leningrad, Meditsina Publ., 1972, 183 p. (in Russian).

33. Makdermott M. Sekrety endokrinologii [Secrets of endocrinology]. Moscow-St. Petersburg, Binom, Nevskiidialekt, 2000, 464 p. (in Russian).

34. Sur'ma «Rvotnyikamen'» ["Emetic stone" antimony]. Available at: http://pharmacognosy.com.ua/index.php/makro-i-mikro-chudesa/surma-rvotniy-kamen (21.12.2017) (in Russian).

35. Klinicheskaya mikroelementologiya. Sur'ma [Clinical microelemntology. Antimony]. Available at: www.microelement.ru/uslovno-toksichnye/99-surma.html (21.03.2018) (in Russian).

36. Chonbasheva Ch.K., Sulaimanova Ch.T. Khronicheskaya sur'myanaya intoksikatsiya u rabotnikov sovremennogo proizvodstva Kyrgyzstana [Chronic intoxication with antimony in workers employed at contemporary productions in Kyrgyzstan]. Vestnik Kyrgyzsko-Rossiiskogo slavyanskogo universiteta, 2014, vol. 14, no. 5, pp.188-190 (in Russian).

37. K voprosu nakopleniya sur'my v krovi i nekotorykh organakh krys s privitoiopukhol'yu sarkoma-45 (material imetodika) [On accumulation of antimony in blood and some organs of rats with indyced sarcoma-45 (data and methods)]. Medchitalka: meditsinskaya biblioteka. Available at: http://www.medchitalka.ru/voprosy klinicheskoy i eksperimentalnoy onko-

logii/voprosy_eksperimentalnoy_onkologii/3147.html (15.03.2018) (in Russian).

38. Kubatbekov T.S., Aitmatov M.B., Ibraimakunov M. Kumulyatsiyasur'my v biosredakhovets, soderzhashchikhsyavblizisur'makombinata [Accumulation of antimony in bioenvironment of sheeps contained in the vicinity of antimony combine]. Vestnik Rossiiskogo universiteta druzhby narodov. Seriya: Agronomiya i zhivotnovodstvo, 2013, no. 2, pp. 45-50 (in Russian).

39. Posypanov G.S., Dolgodvorov V.E., Zherukov B.Kh. [et al.]. Rastenievodstvo [Crop production]. In: G.S. Posypanov ed. Moscow, Kolos Publ., 2006, 612 p. (in Russian).

40. Endemii i endemicheskie zabolevaniya. Endemiyasur'my [Endemias and endemic diseases. Antimony endemia]. Availableat: http://belki.com.ua/minerali-endemia.html (27.02.2018) (in Russian).

41. L Rikhvanov. P., Baranovskaya N.V., Ignatova T.N., Sudyko A.F., Sandimirova G.P., Pakhomova N.N. Elementny I sostav organov I tkanei cheloveka [Elemental structure of human organs and tissues]. Problemy biogeokhimii I geokhimicheskoi ekologii, 2009, vol. 9, no. 1, pp. 67-77(in Russian).

42. Rikhvanov L.P., Baranovskaya N.V., Ignatova T.N., Sudyko A.F., Sandimirova G.P., Pakhomova N.N. Khimicheskii elementny I sostav organov I tkanei cheloveka i ego ekologicheskoe 
znachenie [Trace elements in human organs and tissues and their significance for environmental monitoring]. Geokhimiya, 2011, no. 7, pp. 779-784 (in Russian).

43. Fernando Barbosa Jr. Toxicology of metals and metalloids: Promising issues for future studies in environmental health and toxicology. Journal of Toxicology and Environmental Health, Part A, 2017, vol. 80, no. 3, pp. 137-144. DOI: 10.1080/15287394.2016.1259475

44. Khaidulina Kh.Kh., Dorofeeva E.V. Endokrinnye razrushiteli (Endocrine Disrupters). Sovremennoe sostoyanie problem [Endocrine disruptors. Present status of the problem]. Toksikologicheskii vestnik, 2013, no. 2, pp. 51-54.

Turbinsky V.V., Bortnikova S.B. Proportions of arsenic and antimony in biogeochemical provinces as health risk factors. Health Risk Analysis, 2018, no. 3, pp. 136-143. DOI: 10.21668/health.risk/2018.3.15.eng

Received: 06.06.2018

Accepted: 06.09.2018

Published: 30.09.2018 